\title{
Prevalence and source analysis of COVID-19 misinformation of 138 countries
}

\author{
Md. Sayeed Al-Zaman \\ Lecturer, Department of Journalism and Media Studies \\ Jahangirnagar University, Savar, Dhaka, Bangladesh \\ Email: msalzaman@juniv.edu
}

\begin{abstract}
This study analyzed 9,657 pieces of misinformation that originated in 138 countries and factchecked by 94 organizations. Collected from Poynter Institute's official website and following a quantitative content analysis method along with descriptive statistical analysis, this research produces some novel insights regarding COVID-19 misinformation. The findings show that India (15.94\%), the US (9.74\%), Brazil $(8.57 \%)$, and Spain $(8.03 \%)$ are the four most misinformation-affected countries. Based on the results, it is presumed that the prevalence of COVID-19 misinformation can have a positive association with the COVID-19 situation. Social media (84.94\%) produces the highest amount of misinformation, and the internet $(90.5 \%)$ as a whole is responsible for most of the COVID-19 misinformation. Moreover, Facebook alone produces $66.87 \%$ misinformation among all social media platforms. Of all countries, India (18.07\%) produced the highest amount of social media misinformation, perhaps thanks to the country's higher internet penetration rate, increasing social media consumption, and users' lack of internet literacy. On the other hand, countries like Turkey, the US, Brazil, and the Philippines where either political control over media is intense or political conservatism is apparent, experienced a higher amount of misinformation from mainstream media, political figures, and celebrities. Although the prevalence of misinformation was the highest in March 2020, given the present trends, it may likely to increase slightly in 2021.
\end{abstract}

Keywords: COVID-19 misinformation; social media; Facebook; Twitter.

\section{Introduction}

This study endeavored to understand the prevalence and source of COVID-19 misinformation around the world. From 2020 until now, a search in scholarly databases (e.g., Scopus and Web of Science) shows that more than 500 research investigated COVID-19 misinformation from different disciplines, such as communication, psychology, politics, and medical sciences (1-9). Apart from disciplinary and thematic analysis, many of such studies investigated the sources of misinformation and misinformation scenarios in different countries as well $(4,9-$ 11). However, these studies are limited in one or more of the following ways: (a) they 
selected either only one or a very few countries for their analysis of misinformation; (b) their sample of misinformation cases were smaller compared to its higher prevalence; (c) insights on misinformation in different countries according to different sources were unavailable; (b) comparative source analysis of misinformation was limited. Therefore, considering these limitations, in the present study, we analyzed 9,657 pieces of misinformation originated from 138 countries and debunked by 94 fact-checking organizations to understand the frequency of misinformation in different countries, sources, and country-wise sources distributions. The results suggest that the prevalence of misinformation does not follow any geographical pattern, rather it might be consistent with the pandemic casualty-led tension and information vacuum. Also, social media poses a big challenge to public health and health communication by producing most of the COVID-19 misinformation. The following discussion is divided into three main sections. In the next section, the details of data collection and analysis have been described.

\section{Methodology}

This exploratory study sought to understand the prevalence and sources of COVID-19 misinformation around the world. Three specific inquiries of this study were:

RQ1: Which countries are most affected by COVID-19 misinformation?

$R Q 2$ : What sources produce most of the COVID-19 misinformation?

$R Q 3:$ What sources of misinformation are dominant in which countries?

The data for this study were collected from the official website of Poynter Institute for Media Studies (https://www.poynter.org/ifcn-covid-19-misinformation). It is a Florida-based nonprofit organization established in 1975, which is actively working on reducing the prevalence of misinformation around the world. The organization has two specialized branches dedicated to fact-checking: PolitiFact and the International Fact-Checking Network (IFCN). From the beginning of the COVID-19 pandemic, Poynter Institute has been combating COVID-19 misinformation and collecting prevalent and popular misinformation cases from different countries, and including them on their website. We collected these data using Web Scraper, an automated scraping extension for web browsers (see more http://webscraper.io). In this automated web scraping, we extracted the claims of misinformation, fact-checkers, sources, dates, countries, types of claims, and explanations of misinformation. We limited our study period from 1 January 2020 to 1 March 2021, although March 2021 only included a single day, i.e., 1 March 2021. During this period, the website included 9,657 COVID-19 misinformation from 94 IFCN-certified fact-checkers. Important to note that the data we collected were publicly available. Such public data are not subject to copyright and can be utilized for research purposes (12). Also, unlike semi-public and private data, our data did not require informed consent (13). Moreover, in recent academic scholarship, ethical scraping for research purposes is permissible (14). Previous studies also used similar web scrapers to 
collect research data (e.g., Hautea, Parks, Takahashi, and Zeng, 2021). Therefore, the data we collected and used in this study were free from ethical obligations.

After collecting the data, at first, we cleaned them by eliminating the unnecessary and fragmented parts. This phase also included language corrections and style corrections. Finally, we chose two variables for our analysis that were relevant to our research questions: country name and misinformation source. The dataset mainly included 9,518 pieces of misinformation from 138 countries, and country names for 139 more misinformation were missing. For RQ1, we calculated the percentage of each country to understand their contributions to the total share of misinformation. We also calculated both aggregate and country-wise monthly misinformation distributions to show the changes in misinformation counts throughout the period. For RQ2, we coded the misinformation sources as follows: social media, mainstream media, popular bodies, other internet sources, and miscellaneous. Previous studies identified online media and mainstream media as the two major media sources of COVID-19 misinformation (4). In this study, however, we divided online media into two types: social media and other internet sources. We further categorized social media and mainstream media according to their media type (e.g., Facebook, Twitter, television, newspaper). In this process, we found that some social media and mainstream media were not specified so that we coded them accordingly. Regarding the category popular bodies, we observed that, in many cases, political figures and organizations, and celebrities have been playing roles in producing and circulating misinformation. Therefore, we introduced it as a new category. This category specifically included four main sources: political parties, groups, and figures (e.g., president); non-political organizations (e.g., religious organization); celebrities, influencers, and popular non-political figures (e.g., film actor); relevant specialists and responsible persons (e.g., doctor). We also observed that except for social media, COVID-19 misinformation had a few more internet sources: we categorized them as online portal and blog. The online portals included online news portals and other websites. Finally, we analyzed the countries and their sources of misinformation using cross-tabulation. Consistent with the research questions, instead of inferential statistics, this study adopted descriptive statistical analyses including frequency and percentage analysis and crosstabulations to analyze and interpret the data. For data preparation and analysis, we used Microsoft Excel 2019 and IBM SPSS Statistics 25. For data visualization, we used Tableau 2020.4, an AI-powered professional data visualization and analysis software.

\section{Results \& Discussion}

The present study aimed at answering three questions on COVID-19 misinformation: most affected countries, most popular sources, and popularity of sources according to the countries. A content analysis along with descriptive statistics analyzed 9,657 pieces of misinformation from 138 countries to answer the research inquiries. To the best of our knowledge, this study dealt with the largest amount of COVID-19 misinformation from the highest number of countries and sources to date. 
The map shows that a few countries in the world suffered from the higher pervasiveness of misinformation (Figure 1). Most of the Asian and African countries had a lower amount of misinformation, while South Asia, and North and South America show a higher amount of misinformation. India had the highest amount of misinformation during the period $(n=1,691$; $15.94 \%)$, followed by the United States $(n=1,032 ; 9.74 \%)$, and Brazil $(n=909 ; 8.57 \%)$ (Table 1). The top four countries include a European country as well, i.e., Spain $(n=852$; $8.03 \%$ ). These four countries had comparatively higher amounts of COVID-19 misinformation than other countries. For example, Columbia is in the fifth position with 400 $(3.77 \%)$ misinformation, which is less than half of Spain's frequency. This result shows that COVID-19 misinformation is not concentrated in some specific geographic areas, rather it is decentralized all over the world. Also, a few countries experience more misinformation than most countries. It seems that misinformation in the top countries is somewhat consistent with the casualties they experienced during the pandemic. That means the prevalence of misinformation may have a positive association with pandemic-led casualties. For example, in both the list of COVID-19 misinformation and COVID-19 casualties, the following ten countries are common among the top fifteen countries: India, the United States (US) Brazil, Spain, France, Turkey, Columbia, Argentina, Italy, and Mexico (16). Since the present paper was unable to establish this correlation, we would like to invite more research to explain this presumption empirically.

The aggregate amount of misinformation is showing a gradual decline after May 2020 with some infrequent and small surges (Figure 2). Misinformation reached its peak in March $2020(n=9,256)$ that started dropping in the subsequent months: 8,416, 4,772, and 2,320 in April, May, and June, respectively. The number reached 752 in February 2021. The trend also shows a downward tendency. However, a forecast shows that the number may likely to increase and remain to 955 pieces of misinformation on average in March-September 2021. Most of the countries including India, the US, Brazil, and Spain experienced a surge in misinformation towards March and July 2020 (Table 2). However, a few countries, such as Georgia, experienced a surge from September to December 2020. Both the aggregated and country-wise misinformation count hint that the prevalence of misinformation could be consistent with the number of casualties. Put another way, misinformation surged before or amid the infection, and death rates surged. For example, from March 2020, India, the US, Brazil, and Spain were experiencing a gradual rise in COVID-19 cases along with COVID-19 misinformation (16). On the other hand, before September, Georgia had almost no or limited COVID-19 cases along with COVID-19 misinformation (17). This result is consistent with the hypothesis of Difonzo and Bordia (2006) who claimed that misinformation has a positive correlation with tension, damages, and information scarcity. However, as stated earlier, since this study could not perform a correlation coefficient analysis between the amount of misinformation and the number of COVID-19 casualties, the hypothesis would remain as subject to further analysis. Previous studies did not analyze the relationship either. A few studies only investigated users' engagement with COVID-19 contents. For instance, a study analyzed Twitter conversations on COVID-19 from January to March 2020 and observed the gradual increase in misinformation with time (7). Another study explored that misinformation also increased with time like general conversations and reached the peak in March 2020 (10). 
Users' engagement with COVID-19 content may increase or decrease based on a few factors, such as negative news on COVID-19, misinformation, and vaccine news (19).

Of the four main sources, social media produced the highest amount of misinformation (84.94\%), followed by other internet sources (5.56\%) (Figure 3). Interestingly, the internetbased sources alone produced $90.5 \%$ of all misinformation. It suggests that the internet is the ultimate producer of COVID-19 misinformation, which requires further attention from both scholars and policymakers of the respected countries where internet-based misinformation is more prevalent. On the contrary, the share of mainstream media in misinformation production was relatively lower $(3.29 \%)$ than the other sources. Misinformation from all sources was consistent from January to December 2020 with a few smaller surges. For example, social media starting from $82.61 \%$ in January reached $88.93 \%$ in December experiencing at least four minor decreases in February, May, July, and November. All sources except other internet sources reached their highest in March 2020: social media reached $23.82 \%$, mainstream media to $28.62 \%$, and popular bodies to $21.16 \%$. Only other internet sources reached the peak (22.16\%) in April. A survey shows that $63.3 \%$ of respondents encounter most of the COVID-19 misinformation in social media than other sources (11). Previous studies focusing on different regions also revealed that despite benefiting the public by providing useful information, social media is producing profuse COVID-19 misinformation $(1,8,11,20,21)$. For that reason, social media is addressed as a "double-edged sword" and social media misinformation is addressed as "an [misinformation] epidemic within the COVID-19 pandemic" $(8,21)$.

In social media, Facebook was the most prominent source of misinformation that alone produced $66.87 \%(n=5,485)$ of the total social media misinformation. WhatsApp, a popular instant messaging application, is in the second position with only $10.22 \%(n=838)$ misinformation. Twitter is in the third position on the list with $8.22 \% \quad(n=674)$ misinformation. Previous studies also explored that these three social media platforms are more responsible for COVID-19 misinformation propagation $(1,4,10,22)$. Approximately 831 $(10.13 \%)$ pieces of social media misinformation and $157(49.37 \%)$ pieces of mainstream media misinformation had no specific platform mentioned. In mainstream media, newspapers $(n=88 ; 27.67 \%)$ produced a higher amount of misinformation than television channels $(n=$ $66 ; 20.75 \%$ ), meaning print media produces more misinformation than broadcast media. The online portal is also an important source of misinformation $(n=453)$ that produced a higher amount of misinformation than mainstream media $(n=318)$ and a few popular social media platforms like YouTube $(n=184)$, Line $(n=82)$, and Instagram $(n=80)$. Of online portals, most of them were news portals, containing unreliable information regarding COVID-19. For example, Asembi News, one of Ghana's biggest news websites, published the following false claim: "Family of three died within days of each other before testing positive for coronavirus."

Of all countries, India produced the highest amount of social media misinformation (18.07\%), followed by Brazil (9.17\%) and the US (8.61\%). The reason for India's social media misinformation epidemic could be: (a) the higher social media penetration rates from the last few years, which may increase further in the next few years (23-25); (b) the increased consumption of social media contents during the pandemic (26); (c) social media users' lack of digital literacy that makes them the victims of misinformation (27). On the other hand, 
Turkey produced the highest amount of mainstream media misinformation (12.32\%), followed by the US (11.20\%) and Georgia (8.40\%). Lack of press freedom, authoritarian control over mainstream media, and the government-endorsed disinformation campaign using the media might be responsible for Turkey's higher mainstream media misinformation $(28,29)$. Interestingly, the US alone produced $31.16 \%$ misinformation from popular bodies, mostly from the political figures, groups, and celebrities, which is unprecedented. Brazil $(9.77 \%)$ and the Philippines $(8.60 \%)$ followed the US in this respect. Some political and sociocultural factors might be responsible for such results. For example, conservative politicians and the political environment is found conducive for COVID-19 misinformation in the US and the public trust on politicians' approach to tackling COVID-19 was much higher in the country $(9,30)$. Also, in the contemporary popular culture of the US, celebrities have significant influence over social and political events and audiences, which could be another reason for this result. In Brazil, on the other hand, President Bolsonaro himself is a champion of COVID-19 denial, and the government itself produces COVID-19 disinformation (31). Studies also found that political conservatism like these countries is associated with higher susceptibility to misinformation (9). Like the previous category, i.e., popular bodies, the US produced the highest amount of misinformation from different internet sources as well (12.94\%), followed by North Macedonia (7.12\%) and Spain (6.63\%). For India, the highest misinformation-producing country, the amount of misinformation from popular bodies $(3.95 \%)$ and various internet sources (2.75) was moderate.

The higher prevalence of misinformation would complicate public health responses and health communication in many countries. Meanwhile, COVID-19 misinformation had claimed many lives around the world (1,32). In countries like India and Bangladesh, religious and political COVID-19 misinformation is propelling interreligious discontents and encouraging superstitions and unscientific health practices (4,33-35). Therefore, proper measures should be sanctioned to control the prevalence of misinformation to reduce health hazards.

\section{Conclusion}

To conclude, this study produced a few novel insights regarding COVID-19 misinformation, which would help to better understand the COVID-19 misinformation climate around the world. Also, because this study utilized the largest COVID-19 misinformation data, the results can be more generalizable. Lastly, the scholars may find the results and methodological aspects useful for their future studies. Beyond the contributions and usefulness, however, this study is limited in a few ways. It relied on the data collected by independent fact-checkers, who often have limited resources to collect, research, and debunk all available claims (10). Also, the data included misinformation from only 94 IFCNapproved fact-checkers around the world, which seem insufficient. As a result, many countries were not on the list and popular misinformation from these countries was not included. For example, BD Fact Check, a Bangladeshi fact-checking organization, debunked 300 pieces of misinformation in March-December 2020, and approximately 150 of them were 
related to the pandemic $(36,37)$, which is missing in the current dataset. It reflects that the amount of COVID-19 misinformation is much higher than that was included in our dataset. Another limitation of the study is that it used only descriptive statistics to observe the variables' frequencies, percentages, and cross-tabulations, but the inclusion of the results from inferential statistics (e.g., association analysis between the variables) would better explain their relationships. Although it was not a requirement for the present study, future studies may consider it and find it useful. 


\section{References}

1. Islam MS, Sarkar T, Khan SH, Kamal AHM, Murshid Hasan SM, Kabir A, et al. COVID-19-Related infodemic and its impact on public health: A global social media analysis. American Journal of Tropical Medicine and Hygiene. 2020 Oct 1;103(4):1621-9.

2. Laato $\mathrm{S}$, Islam $A K M N$, Islam $M N$, Whelan $E$. What drives unverified information sharing and cyberchondria during the COVID-19 pandemic? European Journal of Information Systems [Internet]. 2020 May 3 [cited 2020 Jun 28];29(3):288-305. Available from: https://www.tandfonline.com/doi/abs/10.1080/0960085X.2020.1770632

3. Lu J. Themes and Evolution of Misinformation During the Early Phases of the COVID-19 Outbreak in China-An Application of the Crisis and Emergency Risk Communication Model. Frontiers in Communication. 2020;5(August):1-7.

4. Al-Zaman MS. COVID-19-Related Social Media Fake News in India. Journalism and Media. 2021 Mar 16;2(1):100-14.

5. Pennycook G, McPhetres J, Zhang Y, Lu JG, Rand DG. Fighting COVID-19 Misinformation on Social Media: Experimental Evidence for a Scalable AccuracyNudge Intervention. Psychological Science [Internet]. 2020 Jul 30;31(7):770-80. Available from: http://journals.sagepub.com/doi/10.1177/0956797620939054

6. Erku DA, Belachew SA, Abrha S, Sinnollareddy M, Thomas J, Steadman KJ, et al. When fear and misinformation go viral: Pharmacists' role in deterring medication misinformation during the "infodemic" surrounding COVID-19. Research in Social and Administrative Pharmacy [Internet]. 2020 May 1; Available from: https://linkinghub.elsevier.com/retrieve/pii/S1551741120304551

7. Singh L, Bansal S, Bode L, Budak C, Chi G, Kawintiranon K, et al. A first look at COVID-19 information and misinformation sharing on Twitter. arXiv [Internet]. 2020 Mar 30 [cited 2021 May 7];1-24. Available from: http://arxiv.org/abs/2003.13907

8. Siddiqui MYA, Mushtaq K, Mohamed MFH, Soub HAL, Mohamedali MGH, Yousaf Z. "Social media misinformation"-an epidemic within the COVID-19 pandemic. American Journal of Tropical Medicine and Hygiene. 2020 Aug 1;103(2):920-1.

9. Roozenbeek J, Schneider CR, Dryhurst S, Kerr J, Freeman ALJ, Recchia G, et al. Susceptibility to misinformation about COVID-19 around the world: Susceptibility to COVID misinformation. Royal Society Open Science. 2020 Oct 1;7(10):1-15.

10. Brennen JS, Simon FM, Howard PN, Nielsen RK. Types, sources, and claims of COVID-19 misinformation [Internet]. Reuters Institute for the Study of Journalism. London; 2020. Available from: https://reutersinstitute.politics.ox.ac.uk/types-sourcesand-claims-covid-19-misinformation

11. Gupta L, Gasparyan AY, Misra DP, Agarwal V, Zimba O, Yessirkepov M. Information and misinformation on COVID-19: A cross-sectional survey study. Journal of Korean Medical Science. 2020;35(27):1-11.

12. Zhao B. Web Scraping. In: Encyclopedia of Big Data. Springer; 2017. p. 1-3.

13. Franzke aline shakti, Bechmann A, Zimmer M, Ess CM, Research TA of I. Internet Research: Ethical Guidelines 3.0 Association of Internet Researchers [Internet]. USA; 2020. Available from: https://aoir.org/reports/ethics3.pdf

14. Mancosu M, Vegetti F. What You Can Scrape and What Is Right to Scrape: A Proposal for a Tool to Collect Public Facebook Data. Social Media + Society. 2020 Jul 31;6(3):1-11.

15. Hautea S, Parks P, Takahashi B, Zeng J. Showing They Care (Or Don't): Affective Publics and Ambivalent Climate Activism on TikTok. Social Media + Society [Internet]. 2021 Apr 20;7(2):1-14. Available from: 
http://journals.sagepub.com/doi/10.1177/20563051211012344

16. Worldometer. Reported Cases and Deaths by Country or Territory [Internet]. Worldometer. 2021 [cited 2021 May 6]. Available from: https://www.worldometers.info/coronavirus/

17. Worldometer. Georgia [Internet]. Worldometer. 2021 [cited 2021 May 6]. Available from: https://www.worldometers.info/coronavirus/country/georgia/

18. Difonzo N, Bordia P. Rumor Psychology: Social and Organizational Approaches. Washington, DC: Amer Psychological Assn; 2006. 392 p.

19. Al-Zaman MS. An exploratory study of social media users' engagement with COVID19 vaccine-related content. F1000Research [Internet]. 2021 Mar 24 [cited 2021 Apr 16];10:236. Available from: https://f1000research.com/articles/10-236/v1

20. Farooq F, Rathore FA. COVID-19 Vaccination and the Challenge of Infodemic and Disinformation. Journal of Korean Medical Science [Internet]. 2021 Feb 25 [cited 2021 May 7];36(10):1-4. Available from: https://jkms.org/DOIx.php?id=10.3346/jkms.2021.36.e78

21. Ahmed S. Letter to the Editor: Social Media is a Double-Edged Sword in the COVID19 Pandemic. Journal of Korean Medical Science [Internet]. 2020 Jul 27 [cited 2021 May 7];35(29):1-11. Available from: https://jkms.org/DOIx.php?id=10.3346/jkms.2020.35.e270

22. Cinelli M, Quattrociocchi W, Galeazzi A, Valensise CM, Brugnoli E, Schmidt AL, et al. The COVID-19 social media infodemic. Scientific Reports [Internet]. 2020 Dec 6;10(1):16598. Available from: http://www.nature.com/articles/s41598-020-73510-5

23. StatCounter. Social Media Stats India [Internet]. StatCounter. 2021 [cited 2021 May 7]. Available from: https://gs.statcounter.com/social-media-stats/all/india

24. Statista. India - social media users 2023 [Internet]. Statista. 2020 [cited 2020 Dec 1]. Available from: https://www.statista.com/statistics/278407/number-of-social-networkusers-in-india/

25. Keelery S. India - social network penetration 2015-2025 [Internet]. Statista. 2020 [cited 2020 Sep 22]. Available from: https://www.statista.com/statistics/240960/shareof-indian-population-using-social-networks/

26. Keelery S. Impact of the coronavirus (COVID-19) on media consumption in India as of March 2020, by type of media [Internet]. India; 2020 [cited 2020 Oct 1]. Available from: https://www.statista.com/statistics/1113485/india-coronavirus-impact-on-mediaconsumption-by-media-type/

27. Raj A, Goswami MP. Is fake news spreading more rapidly than COVID-19 in India? Journal of Content, Community and Communication [Internet]. 2020;11(10):208-20. Available from: https://www.amity.edu/gwalior/JCCC/pdf/june_15.pdf

28. Erbey M. Opinion: Turkey's dithering and disinformation in coronavirus outbreak [Internet]. DW. 2020 [cited 2021 May 7]. Available from: https://www.dw.com/en/opinion-coronavirus-in-turkey/a-53039740

29. DW. China, Turkey jail more journalists than any other country: report [Internet]. DW. 2019 [cited 2021 May 7]. Available from: https://www.dw.com/en/china-turkey-jailmore-journalists-than-any-other-country-report/a-51619255

30. Calvillo DP, Ross BJ, Garcia RJB, Smelter TJ, Rutchick AM. Political Ideology Predicts Perceptions of the Threat of COVID-19 (and Susceptibility to Fake News About It). Social Psychological and Personality Science [Internet]. 2020 Nov 22 [cited 2021 May 7];11(8):1119-28. Available from: http://journals.sagepub.com/doi/10.1177/1948550620940539

31. Ricard J, Medeiros J. Using Misinformation as a Political Weapon: COVID-19 AND Bolsonaro In Brazil. Harvard Kennedy School Misinformation Review [Internet]. 2020 
Apr 16 [cited 2021 May 7];1(3). Available from: https://doi.org/10.37016/mr-2020013

32. Coleman A. "Hundreds dead" because of Covid-19 misinformation [Internet]. BBC News. 2020 [cited 2020 Aug 14]. Available from: https://www.bbc.com/news/world53755067

33. Sarkar S. Religious discrimination is hindering the covid-19 response. BMJ (Clinical research ed) [Internet]. 2020 Jun 29 [cited 2020 Sep 3];369:m2280. Available from: http://dx.doi.org/10.1136/bmj.m2280

34. Menon S. Coronavirus: The human cost of fake news in India. BBC News [Internet]. 2020 Jun 30 [cited 2020 Sep 20]; Available from: https://www.bbc.com/news/worldasia-india-53165436

35. Sutaria S. Coronavirus Misinformation in India Is Not Limited to Health Misinformation [Internet]. Delhi, India; 2020 Jul [cited 2020 Sep 20]. Available from: https://meedan.com/reports/coronavirus-misinformation-in-india-is-not-limited-tohealth-misinformation/

36. Somoynews. BD Fact Check is increasing awareness by detecting rumors [Internet]. Somoynews.tv. 2020 [cited 2021 Apr 16]. Available from: https://www.somoynews.tv/pages/details/252215

37. Khan JJ. Debunking fake news in Bangladesh [Internet]. The Daily Star. 2020 [cited 2021 Apr 16]. Available from: https://www.thedailystar.net/toggle/news/debunkingfake-news-bangladesh-1904980 
medRxiv preprint doi: https://doi.org/10.1101/2021.05.08.21256879; this version posted May 12, 2021. The copyright holder for this preprint (which was not certified by peer review) is the author/funder, who has granted medRxiv a license to display the preprint in perpetuity.

It is made available under a CC-BY-NC-ND 4.0 International license .

Tables \& Figures

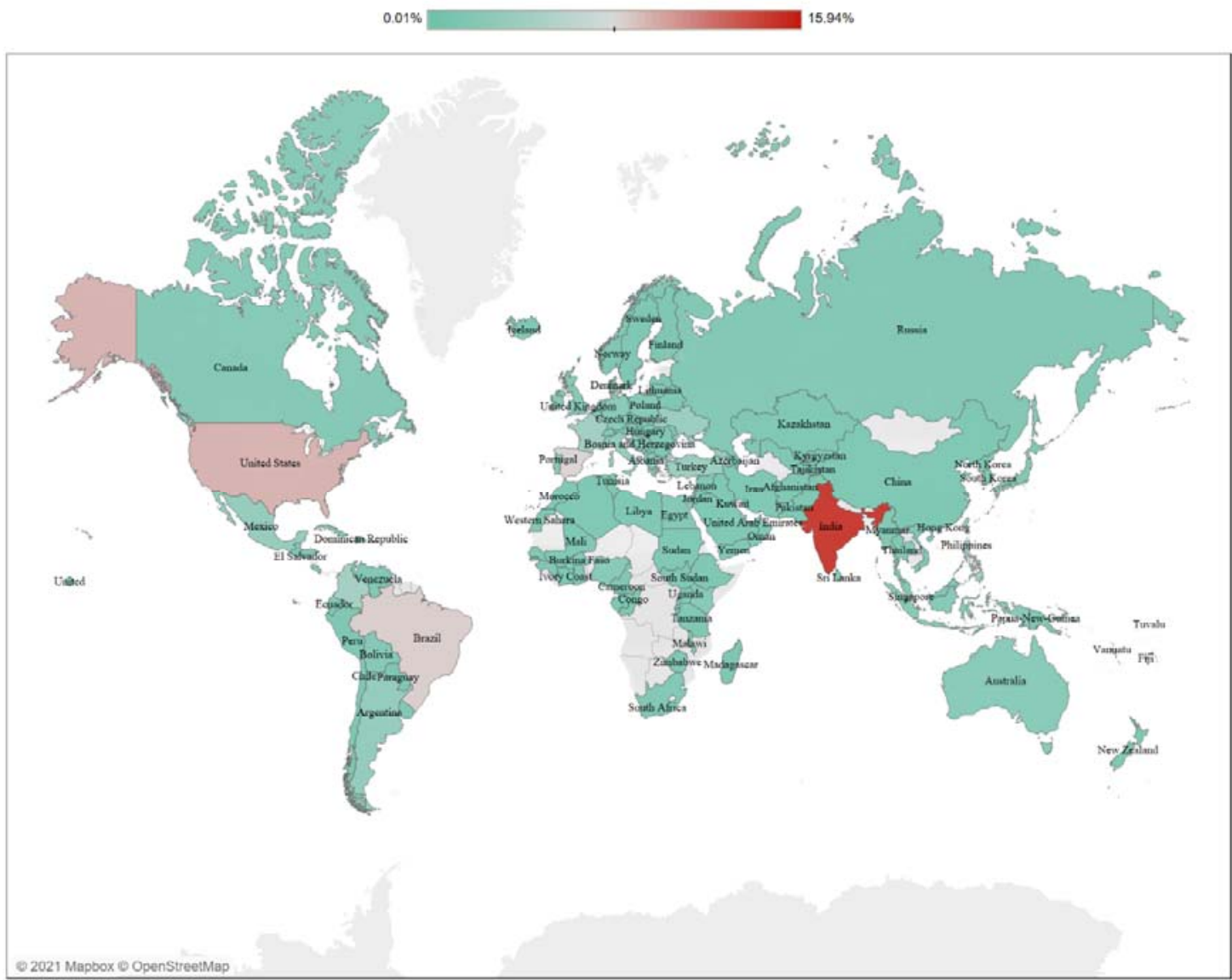

Figure 1. Percentage map of the COVID-19 misinformation.

Table 1. Countries and their counts of COVID-19 misinformation.

\begin{tabular}{|c|c|c|c|c|c|c|c|}
\hline Rank & Country & Frequency & Percentage & Rank & Country & Frequency & Percentage \\
\hline 1 & India & 1691 & $15.94 \%$ & 71 & Algeria & 10 & $0.09 \%$ \\
\hline 2 & United States & 1032 & $9.74 \%$ & 72 & Kyrgyzstan & 10 & $0.09 \%$ \\
\hline 3 & Brazil & 909 & $8.57 \%$ & 73 & Mali & 10 & $0.09 \%$ \\
\hline 4 & Spain & 852 & $8.03 \%$ & 74 & Singapore & 10 & $0.09 \%$ \\
\hline 5 & Colombia & 400 & $3.77 \%$ & 75 & Burundi & 9 & $0.08 \%$ \\
\hline 6 & France & 356 & $3.36 \%$ & 76 & Madagascar & 9 & $0.08 \%$ \\
\hline 7 & Philippines & 339 & $3.20 \%$ & 77 & Saudi Arabia & 9 & $0.08 \%$ \\
\hline 8 & Ukraine & 300 & $2.83 \%$ & 78 & Syria & 9 & $0.08 \%$ \\
\hline 9 & Turkey & 288 & $2.72 \%$ & 79 & Chile & 8 & $0.08 \%$ \\
\hline 10 & Mexico & 250 & $2.36 \%$ & 80 & Ethiopia & 8 & $0.08 \%$ \\
\hline 11 & Argentina & 235 & $2.22 \%$ & 81 & Ivory Coast & 8 & $0.08 \%$ \\
\hline 12 & Italy & 231 & $2.18 \%$ & 82 & Sweden & 8 & $0.08 \%$ \\
\hline 13 & Taiwan & 223 & $2.10 \%$ & 83 & Belarus & 7 & $0.07 \%$ \\
\hline 14 & Georgia & 212 & $2.00 \%$ & 84 & Cameroon & 7 & $0.07 \%$ \\
\hline 15 & North Macedonia & 167 & $1.57 \%$ & 85 & Europe & 7 & $0.07 \%$ \\
\hline 16 & Missing & 139 & $1.31 \%$ & 86 & Iraq & 7 & $0.07 \%$ \\
\hline 17 & Australia & 131 & $1.24 \%$ & 87 & Senegal & 7 & $0.07 \%$ \\
\hline 18 & Germany & 129 & $1.22 \%$ & 88 & Austria & 5 & $0.05 \%$ \\
\hline 19 & Sri Lanka & 119 & $1.12 \%$ & 89 & Cuba & 5 & $0.05 \%$ \\
\hline 20 & Middle East & 116 & $1.09 \%$ & 90 & $\begin{array}{l}\text { United Arab } \\
\text { Emirates }\end{array}$ & 5 & $0.05 \%$ \\
\hline
\end{tabular}




\begin{tabular}{|c|c|c|c|c|c|c|c|}
\hline 21 & Indonesia & 115 & $1.08 \%$ & 91 & Lebanon & 4 & $0.04 \%$ \\
\hline 22 & Kenya & 115 & $1.08 \%$ & 92 & South Sudan & 4 & $0.04 \%$ \\
\hline 23 & Nigeria & 106 & $1.00 \%$ & 93 & Southern Africa & 4 & $0.04 \%$ \\
\hline 24 & North Africa & 101 & $0.95 \%$ & 94 & Bulgaria & 3 & $0.03 \%$ \\
\hline 25 & Ecuador & 95 & $0.90 \%$ & 95 & El Salvador & 3 & $0.03 \%$ \\
\hline 26 & Canada & 92 & $0.87 \%$ & 96 & Gabon & 3 & $0.03 \%$ \\
\hline 27 & Portugal & 89 & $0.84 \%$ & 97 & Libya & 3 & $0.03 \%$ \\
\hline 28 & Poland & 84 & $0.79 \%$ & 98 & Montenegro & 3 & $0.03 \%$ \\
\hline 29 & Ireland & 83 & $0.78 \%$ & 99 & Romania & 3 & $0.03 \%$ \\
\hline 30 & Croatia & 78 & $0.74 \%$ & 100 & Uruguay & 3 & $0.03 \%$ \\
\hline 31 & Bolivia & 71 & $0.67 \%$ & 101 & Zimbabwe & 3 & $0.03 \%$ \\
\hline 32 & United Kingdom & 70 & $0.66 \%$ & 102 & Afghanistan & 2 & $0.02 \%$ \\
\hline 33 & Myanmar & 65 & $0.61 \%$ & 103 & Asia & 2 & $0.02 \%$ \\
\hline 34 & Greece & 64 & $0.60 \%$ & 104 & Azerbaijan & 2 & $0.02 \%$ \\
\hline 35 & Venezuela & 64 & $0.60 \%$ & 105 & Czech Republic & 2 & $0.02 \%$ \\
\hline 36 & Japan & 58 & $0.55 \%$ & 106 & Finland & 2 & $0.02 \%$ \\
\hline 37 & Lithuania & 56 & $0.53 \%$ & 107 & Guinea & 2 & $0.02 \%$ \\
\hline 38 & Ghana & 45 & $0.42 \%$ & 108 & Iceland & 2 & $0.02 \%$ \\
\hline 39 & Russia & 43 & $0.41 \%$ & 109 & Kuwait & 2 & $0.02 \%$ \\
\hline 40 & South Africa & 43 & $0.41 \%$ & 110 & North America & 2 & $0.02 \%$ \\
\hline 41 & Egypt & 42 & $0.40 \%$ & 111 & Norway & 2 & $0.02 \%$ \\
\hline 42 & Thailand & 40 & $0.38 \%$ & 112 & South America & 2 & $0.02 \%$ \\
\hline 43 & Costa Rica & 39 & $0.37 \%$ & 113 & Switzerland & 2 & $0.02 \%$ \\
\hline 44 & $\begin{array}{l}\text { Bosnia and } \\
\text { Herzegovina }\end{array}$ & 37 & $0.35 \%$ & 114 & Yemen & 2 & $0.02 \%$ \\
\hline 45 & Belgium & 35 & $0.33 \%$ & 115 & Albania & 1 & $0.01 \%$ \\
\hline 46 & Hong Kong & 35 & $0.33 \%$ & 116 & Bahrain & 1 & $0.01 \%$ \\
\hline 47 & Serbia & 35 & $0.33 \%$ & 117 & Burkina Faso & 1 & $0.01 \%$ \\
\hline 48 & China & 33 & $0.31 \%$ & 118 & Central America & 1 & $0.01 \%$ \\
\hline 49 & Kazakhstan & 31 & $0.29 \%$ & 119 & $\begin{array}{l}\text { Dominican } \\
\text { Republic }\end{array}$ & 1 & $0.01 \%$ \\
\hline 50 & Peru & 31 & $0.29 \%$ & 120 & Fiji & 1 & $0.01 \%$ \\
\hline 51 & Netherlands & 27 & $0.25 \%$ & 121 & Gambia & 1 & $0.01 \%$ \\
\hline 52 & South Korea & 25 & $0.24 \%$ & 122 & Honduras & 1 & $0.01 \%$ \\
\hline 53 & Latvia & 23 & $0.22 \%$ & 123 & Hungary & 1 & $0.01 \%$ \\
\hline 54 & Pakistan & 22 & $0.21 \%$ & 124 & Kosovo & 1 & $0.01 \%$ \\
\hline 55 & Paraguay & 21 & $0.20 \%$ & 125 & Malawi & 1 & $0.01 \%$ \\
\hline 56 & Tunisia & 21 & $0.20 \%$ & 126 & Moldova & 1 & $0.01 \%$ \\
\hline 57 & Western Sahara & 19 & $0.18 \%$ & 127 & North Korea & 1 & $0.01 \%$ \\
\hline 58 & Jordan & 17 & $0.16 \%$ & 128 & Oman & 1 & $0.01 \%$ \\
\hline 59 & Uganda & 17 & $0.16 \%$ & 129 & $\begin{array}{l}\text { Papua-New- } \\
\text { Guinea }\end{array}$ & 1 & $0.01 \%$ \\
\hline 60 & Denmark & 16 & $0.15 \%$ & 130 & Qatar & 1 & $0.01 \%$ \\
\hline 61 & East Africa & 16 & $0.15 \%$ & 131 & Rwanda & 1 & $0.01 \%$ \\
\hline 62 & New Zealand & 16 & $0.15 \%$ & 132 & Slovakia & 1 & $0.01 \%$ \\
\hline 63 & Tanzania & 16 & $0.15 \%$ & 133 & Sudan & 1 & $0.01 \%$ \\
\hline 64 & Africa & 15 & $0.14 \%$ & 134 & Tajikistan & 1 & $0.01 \%$ \\
\hline 65 & Israel & 15 & $0.14 \%$ & 135 & Timor Leste & 1 & $0.01 \%$ \\
\hline 66 & Guatemala & 14 & $0.13 \%$ & 136 & Tuvalu & 1 & $0.01 \%$ \\
\hline 67 & Malaysia & 13 & $0.12 \%$ & 137 & Uzbekistan & 1 & $0.01 \%$ \\
\hline 68 & Congo & 11 & $0.10 \%$ & 138 & Vanuatu & 1 & $0.01 \%$ \\
\hline 69 & Iran & 11 & $0.10 \%$ & 139 & Vietnam & 1 & $0.01 \%$ \\
\hline 70 & Morocco & 11 & $0.10 \%$ & & & & \\
\hline
\end{tabular}


medRxiv preprint doi: https://doi.org/10.1101/2021.05.08.21256879; this version posted May 12, 2021. The copyright holder for this preprint (which was not certified by peer review) is the author/funder, who has granted medRxiv a license to display the preprint in perpetuity.

It is made available under a CC-BY-NC-ND 4.0 International license .

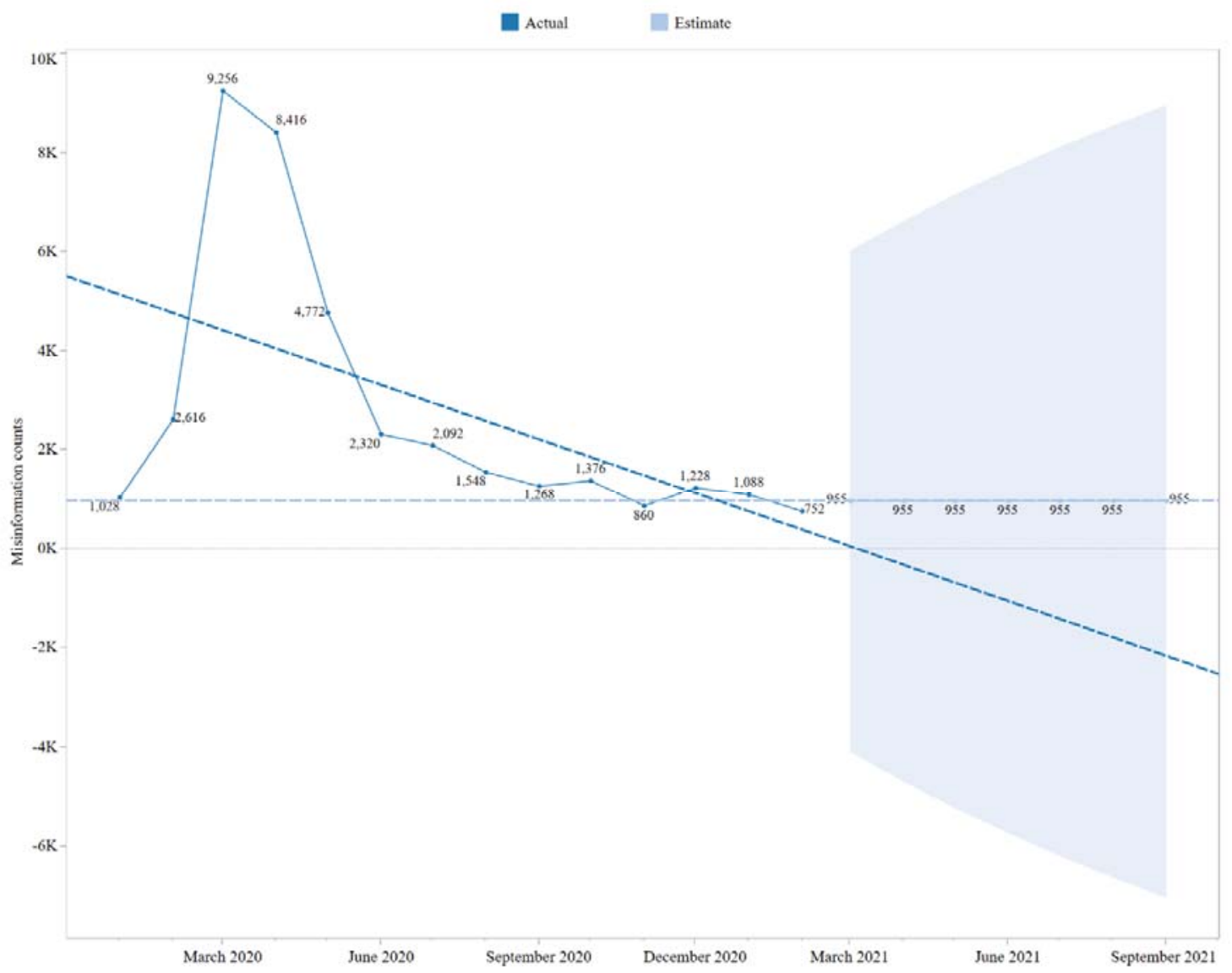

Figure 2. Misinformation trends during the period and a trend-based forecast. 
Table 2. Monthly frequency distributions of misinformation according to the countries.

\begin{tabular}{|c|c|c|c|c|c|c|c|c|c|c|c|c|c|c|c|}
\hline Country & Jan 20 & Feb 20 & Mar 20 & Apr 20 & May 20 & Jun 20 & Jul 20 & Aug 20 & Sep 20 & Oct 20 & Nov 20 & Dec 20 & Jan 21 & Feb 21 & Mar 21 \\
\hline Afghanistan & 0 & 0 & 1 & 1 & 0 & 0 & 0 & 0 & 0 & 0 & 0 & 0 & 0 & 0 & 0 \\
\hline Africa & 0 & 0 & 4 & 6 & 3 & 2 & 0 & 0 & 0 & 0 & 0 & 0 & 0 & 0 & 0 \\
\hline Albania & 0 & 0 & 1 & 0 & 0 & 0 & 0 & 0 & 0 & 0 & 0 & 0 & 0 & 0 & 0 \\
\hline Algeria & 1 & 0 & 4 & 3 & 1 & 0 & 0 & 1 & 0 & 0 & 0 & 0 & 0 & 0 & 0 \\
\hline Argentina & 1 & 4 & 24 & 35 & 30 & 26 & 22 & 21 & 24 & 17 & 7 & 5 & 10 & 9 & 0 \\
\hline Asia & 1 & 0 & 0 & 1 & 0 & 0 & 0 & 0 & 0 & 0 & 0 & 0 & 0 & 0 & 0 \\
\hline Australia & 4 & 7 & 32 & 18 & 5 & 9 & 13 & 9 & 10 & 8 & 2 & 10 & 1 & 3 & 0 \\
\hline Austria & 0 & 0 & 0 & 0 & 0 & 0 & 0 & 1 & 0 & 1 & 1 & 1 & 1 & 0 & 0 \\
\hline Azerbaijan & 0 & 0 & 1 & 1 & 0 & 0 & 0 & 0 & 0 & 0 & 0 & 0 & 0 & 0 & 0 \\
\hline Bahrain & 0 & 0 & 1 & 0 & 0 & 0 & 0 & 0 & 0 & 0 & 0 & 0 & 0 & 0 & 0 \\
\hline Belarus & 0 & 0 & 1 & 0 & 3 & 1 & 1 & 0 & 0 & 1 & 0 & 0 & 0 & 0 & 0 \\
\hline Belgium & 1 & 0 & 6 & 4 & 4 & 1 & 6 & 2 & 5 & 2 & 1 & 2 & 1 & 0 & 0 \\
\hline Bolivia & 0 & 0 & 8 & 21 & 3 & 10 & 13 & 10 & 4 & 1 & 0 & 0 & 1 & 0 & 0 \\
\hline Bosnia and Herzegovina & 6 & 4 & 9 & 6 & 11 & 1 & 0 & 0 & 0 & 0 & 0 & 0 & 0 & 0 & 0 \\
\hline Brazil & 19 & 8 & 105 & 150 & 101 & 83 & 101 & 69 & 45 & 48 & 25 & 57 & 62 & 36 & 0 \\
\hline Bulgaria & 0 & 0 & 1 & 0 & 0 & 0 & 2 & 0 & 0 & 0 & 0 & 0 & 0 & 0 & 0 \\
\hline Burkina Faso & 0 & 0 & 0 & 1 & 0 & 0 & 0 & 0 & 0 & 0 & 0 & 0 & 0 & 0 & 0 \\
\hline Burundi & 0 & 0 & 0 & 0 & 8 & 1 & 0 & 0 & 0 & 0 & 0 & 0 & 0 & 0 & 0 \\
\hline Cameroon & 0 & 1 & 3 & 1 & 2 & 0 & 0 & 0 & 0 & 0 & 0 & 0 & 0 & 0 & 0 \\
\hline Canada & 6 & 4 & 28 & 17 & 7 & 6 & 5 & 3 & 4 & 5 & 3 & 0 & 1 & 3 & 0 \\
\hline Central America & 0 & 0 & 0 & 0 & 1 & 0 & 0 & 0 & 0 & 0 & 0 & 0 & 0 & 0 & 0 \\
\hline Chile & 0 & 0 & 1 & 2 & 1 & 0 & 0 & 0 & 3 & 1 & 0 & 0 & 0 & 0 & 0 \\
\hline China & 1 & 3 & 11 & 11 & 3 & 2 & 0 & 0 & 0 & 1 & 0 & 0 & 0 & 1 & 0 \\
\hline Colombia & 5 & 10 & 65 & 51 & 49 & 50 & 55 & 37 & 17 & 9 & 11 & 3 & 21 & 17 & 0 \\
\hline Congo & 0 & 0 & 5 & 2 & 1 & 2 & 0 & 0 & 1 & 0 & 0 & 0 & 0 & 0 & 0 \\
\hline Costa Rica & 0 & 0 & 8 & 21 & 1 & 0 & 9 & 0 & 0 & 0 & 0 & 0 & 0 & 0 & 0 \\
\hline Croatia & 3 & 3 & 37 & 30 & 3 & 1 & 0 & 0 & 0 & 1 & 0 & 0 & 0 & 0 & 0 \\
\hline Cuba & 0 & 0 & 0 & 5 & 0 & 0 & 0 & 0 & 0 & 0 & 0 & 0 & 0 & 0 & 0 \\
\hline Czech Republic & 0 & 0 & 2 & 0 & 0 & 0 & 0 & 0 & 0 & 0 & 0 & 0 & 0 & 0 & 0 \\
\hline Denmark & 2 & 0 & 8 & 2 & 4 & 0 & 0 & 0 & 0 & 0 & 0 & 0 & 0 & 0 & 0 \\
\hline Dominican Republic & 0 & 0 & 0 & 1 & 0 & 0 & 0 & 0 & 0 & 0 & 0 & 0 & 0 & 0 & 0 \\
\hline East Africa & 0 & 0 & 13 & 2 & 1 & 0 & 0 & 0 & 0 & 0 & 0 & 0 & 0 & 0 & 0 \\
\hline Ecuador & 4 & 7 & 71 & 5 & 3 & 1 & 3 & 0 & 1 & 0 & 0 & 0 & 0 & 0 & 0 \\
\hline Egypt & 0 & 2 & 3 & 11 & 13 & 9 & 1 & 3 & 0 & 0 & 0 & 0 & 0 & 0 & 0 \\
\hline El Salvador & 0 & 0 & 1 & 1 & 0 & 0 & 0 & 1 & 0 & 0 & 0 & 0 & 0 & 0 & 0 \\
\hline Ethiopia & 0 & 1 & 2 & 0 & 3 & 0 & 0 & 0 & 0 & 1 & 0 & 0 & 1 & 0 & 0 \\
\hline Europe & 0 & 1 & 2 & 1 & 3 & 0 & 0 & 0 & 0 & 0 & 0 & 0 & 0 & 0 & 0 \\
\hline
\end{tabular}




\begin{tabular}{|c|c|c|c|c|c|c|c|c|c|c|c|c|c|c|}
\hline Fiji & 0 & 0 & 0 & 1 & 0 & 0 & 0 & 0 & 0 & 0 & 0 & 0 & 0 & 0 \\
\hline Finland & 0 & 0 & 0 & 0 & 0 & 0 & 0 & 0 & 0 & 2 & 0 & 0 & 0 & 0 \\
\hline France & 12 & 18 & 106 & 76 & 35 & 18 & 14 & 10 & 22 & 19 & 5 & 13 & 5 & 3 \\
\hline Gabon & 0 & 1 & 0 & 0 & 1 & 0 & 0 & 0 & 0 & 0 & 1 & 0 & 0 & 0 \\
\hline Gambia & 0 & 0 & 0 & 1 & 0 & 0 & 0 & 0 & 0 & 0 & 0 & 0 & 0 & 0 \\
\hline Georgia & 2 & 1 & 4 & 6 & 8 & 4 & 7 & 11 & 26 & 39 & 32 & 34 & 26 & 12 \\
\hline Germany & 1 & 3 & 11 & 14 & 6 & 10 & 16 & 17 & 6 & 15 & 14 & 8 & 8 & 0 \\
\hline Ghana & 1 & 0 & 13 & 14 & 15 & 0 & 2 & 0 & 0 & 0 & 0 & 0 & 0 & 0 \\
\hline Greece & 4 & 3 & 20 & 18 & 9 & 4 & 5 & 1 & 0 & 0 & 0 & 0 & 0 & 0 \\
\hline Guatemala & 0 & 0 & 6 & 2 & 4 & 0 & 0 & 0 & 1 & 0 & 0 & 0 & 1 & 0 \\
\hline Guinea & 0 & 0 & 0 & 1 & 1 & 0 & 0 & 0 & 0 & 0 & 0 & 0 & 0 & 0 \\
\hline Honduras & 0 & 0 & 0 & 0 & 0 & 0 & 1 & 0 & 0 & 0 & 0 & 0 & 0 & 0 \\
\hline Hong Kong & 0 & 9 & 16 & 8 & 1 & 0 & 0 & 0 & 0 & 0 & 0 & 0 & 0 & 1 \\
\hline Hungary & 0 & 0 & 0 & 1 & 0 & 0 & 0 & 0 & 0 & 0 & 0 & 0 & 0 & 0 \\
\hline Iceland & 0 & 0 & 2 & 0 & 0 & 0 & 0 & 0 & 0 & 0 & 0 & 0 & 0 & 0 \\
\hline India & 25 & 92 & 425 & 592 & 299 & 97 & 59 & 35 & 15 & 14 & 7 & 12 & 17 & 2 \\
\hline Indonesia & 8 & 20 & 39 & 16 & 17 & 9 & 0 & 1 & 1 & 0 & 0 & 0 & 4 & 0 \\
\hline Iran & 0 & 5 & 5 & 1 & 0 & 0 & 0 & 0 & 0 & 0 & 0 & 0 & 0 & 0 \\
\hline Iraq & 0 & 0 & 0 & 2 & 2 & 3 & 0 & 0 & 0 & 0 & 0 & 0 & 0 & 0 \\
\hline Israel & 0 & 0 & 3 & 2 & 3 & 0 & 3 & 1 & 0 & 1 & 0 & 1 & 1 & 0 \\
\hline Italy & 6 & 33 & 46 & 45 & 45 & 20 & 11 & 8 & 1 & 4 & 1 & 1 & 1 & 8 \\
\hline Ivory Coast & 0 & 0 & 5 & 2 & 0 & 0 & 0 & 0 & 1 & 0 & 0 & 0 & 0 & 0 \\
\hline Japan & 6 & 11 & 7 & 12 & 7 & 2 & 3 & 3 & 0 & 2 & 0 & 3 & 1 & 1 \\
\hline Jordan & 0 & 2 & 1 & 3 & 8 & 2 & 0 & 1 & 0 & 0 & 0 & 0 & 0 & 0 \\
\hline Kazakhstan & 2 & 2 & 7 & 13 & 7 & 0 & 0 & 0 & 0 & 0 & 0 & 0 & 0 & 0 \\
\hline Kenya & 2 & 5 & 40 & 43 & 21 & 1 & 0 & 1 & 1 & 0 & 0 & 0 & 1 & 0 \\
\hline Kosovo & 0 & 0 & 1 & 0 & 0 & 0 & 0 & 0 & 0 & 0 & 0 & 0 & 0 & 0 \\
\hline Kuwait & 0 & 0 & 1 & 1 & 0 & 0 & 0 & 0 & 0 & 0 & 0 & 0 & 0 & 0 \\
\hline Kyrgyzstan & 0 & 1 & 3 & 3 & 3 & 0 & 0 & 0 & 0 & 0 & 0 & 0 & 0 & 0 \\
\hline Latvia & 0 & 0 & 5 & 5 & 7 & 2 & 0 & 0 & 0 & 0 & 1 & 1 & 0 & 2 \\
\hline Lebanon & 0 & 0 & 0 & 1 & 1 & 1 & 0 & 1 & 0 & 0 & 0 & 0 & 0 & 0 \\
\hline Libya & 1 & 0 & 0 & 1 & 0 & 0 & 1 & 0 & 0 & 0 & 0 & 0 & 0 & 0 \\
\hline Lithuania & 1 & 11 & 18 & 14 & 12 & 0 & 0 & 0 & 0 & 0 & 0 & 0 & 0 & 0 \\
\hline Madagascar & 0 & 0 & 0 & 3 & 6 & 0 & 0 & 0 & 0 & 0 & 0 & 0 & 0 & 0 \\
\hline Malawi & 0 & 0 & 0 & 0 & 0 & 1 & 0 & 0 & 0 & 0 & 0 & 0 & 0 & 0 \\
\hline Malaysia & 1 & 0 & 4 & 4 & 1 & 0 & 0 & 0 & 0 & 0 & 0 & 1 & 1 & 1 \\
\hline Mali & 0 & 0 & 0 & 7 & 2 & 1 & 0 & 0 & 0 & 0 & 0 & 0 & 0 & 0 \\
\hline
\end{tabular}




\begin{tabular}{|c|c|c|c|c|c|c|c|c|c|c|c|c|c|c|}
\hline Middle East & 3 & 16 & 61 & 31 & 0 & 2 & 1 & 1 & 0 & 0 & 0 & 0 & 0 & 1 \\
\hline Missing & 1 & 7 & 36 & 23 & 15 & 10 & 23 & 9 & 5 & 4 & 2 & 0 & 3 & 1 \\
\hline Moldova & 0 & 0 & 0 & 1 & 0 & 0 & 0 & 0 & 0 & 0 & 0 & 0 & 0 & 0 \\
\hline Montenegro & 3 & 0 & 0 & 0 & 0 & 0 & 0 & 0 & 0 & 0 & 0 & 0 & 0 & 0 \\
\hline Morocco & 0 & 2 & 4 & 2 & 1 & 0 & 1 & 1 & 0 & 0 & 0 & 0 & 0 & 0 \\
\hline Myanmar & 0 & 0 & 19 & 19 & 24 & 2 & 0 & 0 & 0 & 1 & 0 & 0 & 0 & 0 \\
\hline Netherlands & 0 & 0 & 6 & 7 & 8 & 0 & 1 & 0 & 0 & 2 & 0 & 1 & 1 & 1 \\
\hline New Zealand & 0 & 0 & 0 & 2 & 1 & 1 & 2 & 4 & 1 & 2 & 1 & 1 & 1 & 0 \\
\hline Nigeria & 1 & 7 & 38 & 40 & 9 & 7 & 0 & 0 & 1 & 0 & 1 & 0 & 1 & 1 \\
\hline North Africa & 3 & 16 & 59 & 22 & 0 & 0 & 0 & 0 & 0 & 0 & 0 & 0 & 0 & 1 \\
\hline North America & 0 & 0 & 0 & 0 & 2 & 0 & 0 & 0 & 0 & 0 & 0 & 0 & 0 & 0 \\
\hline North Korea & 0 & 0 & 1 & 0 & 0 & 0 & 0 & 0 & 0 & 0 & 0 & 0 & 0 & 0 \\
\hline North Macedonia & 2 & 6 & 34 & 11 & 5 & 5 & 5 & 4 & 13 & 27 & 14 & 17 & 12 & 12 \\
\hline Norway & 0 & 0 & 0 & 0 & 0 & 0 & 0 & 0 & 0 & 0 & 0 & 0 & 2 & 0 \\
\hline Oman & 0 & 0 & 1 & 0 & 0 & 0 & 0 & 0 & 0 & 0 & 0 & 0 & 0 & 0 \\
\hline Pakistan & 1 & 4 & 7 & 2 & 3 & 1 & 0 & 0 & 0 & 0 & 2 & 1 & 1 & 0 \\
\hline Papua-New-Guinea & 0 & 0 & 0 & 0 & 0 & 0 & 0 & 0 & 1 & 0 & 0 & 0 & 0 & 0 \\
\hline Paraguay & 0 & 0 & 8 & 4 & 7 & 2 & 0 & 0 & 0 & 0 & 0 & 0 & 0 & 0 \\
\hline Peru & 0 & 0 & 16 & 4 & 5 & 2 & 0 & 2 & 0 & 0 & 0 & 0 & 1 & 1 \\
\hline Poland & 2 & 3 & 20 & 10 & 13 & 2 & 3 & 6 & 13 & 2 & 1 & 0 & 5 & 4 \\
\hline Portugal & 0 & 5 & 33 & 21 & 16 & 5 & 8 & 0 & 0 & 1 & 0 & 0 & 0 & 0 \\
\hline Qatar & 0 & 0 & 1 & 0 & 0 & 0 & 0 & 0 & 0 & 0 & 0 & 0 & 0 & 0 \\
\hline Romania & 0 & 0 & 0 & 1 & 0 & 0 & 0 & 0 & 0 & 0 & 0 & 0 & 0 & 1 \\
\hline Russia & 2 & 2 & 14 & 10 & 6 & 1 & 1 & 2 & 0 & 3 & 1 & 0 & 0 & 1 \\
\hline Rwanda & 0 & 0 & 0 & 1 & 0 & 0 & 0 & 0 & 0 & 0 & 0 & 0 & 0 & 0 \\
\hline Saudi Arabia & 0 & 0 & 1 & 4 & 2 & 1 & 0 & 0 & 0 & 0 & 0 & 0 & 1 & 0 \\
\hline Senegal & 0 & 1 & 2 & 3 & 0 & 0 & 0 & 0 & 0 & 0 & 0 & 1 & 0 & 0 \\
\hline Serbia & 3 & 2 & 11 & 9 & 4 & 1 & 0 & 0 & 4 & 0 & 0 & 0 & 0 & 1 \\
\hline Singapore & 1 & 0 & 3 & 2 & 2 & 0 & 1 & 0 & 1 & 0 & 0 & 0 & 0 & 0 \\
\hline Slovakia & 0 & 0 & 1 & 0 & 0 & 0 & 0 & 0 & 0 & 0 & 0 & 0 & 0 & 0 \\
\hline South Africa & 0 & 1 & 16 & 16 & 3 & 1 & 1 & 0 & 1 & 1 & 1 & 0 & 1 & 1 \\
\hline South America & 0 & 0 & 1 & 0 & 1 & 0 & 0 & 0 & 0 & 0 & 0 & 0 & 0 & 0 \\
\hline South Korea & 2 & 10 & 4 & 1 & 0 & 0 & 0 & 1 & 2 & 0 & 0 & 1 & 1 & 3 \\
\hline South Sudan & 0 & 0 & 0 & 1 & 3 & 0 & 0 & 0 & 0 & 0 & 0 & 0 & 0 & 0 \\
\hline Southern Africa & 0 & 0 & 2 & 2 & 0 & 0 & 0 & 0 & 0 & 0 & 0 & 0 & 0 & 0 \\
\hline Spain & 25 & 64 & 227 & 141 & 63 & 49 & 42 & 24 & 20 & 60 & 27 & 44 & 32 & 33 \\
\hline Sri Lanka & 3 & 3 & 36 & 38 & 27 & 5 & 2 & 0 & 0 & 2 & 1 & 1 & 0 & 1 \\
\hline
\end{tabular}




\begin{tabular}{|c|c|c|c|c|c|c|c|c|c|c|c|c|c|c|c|}
\hline Sweden & 1 & 0 & 3 & 0 & 2 & 0 & 0 & 0 & 0 & 2 & 0 & 0 & 0 & 0 & 0 \\
\hline Switzerland & 0 & 0 & 0 & 0 & 1 & 0 & 0 & 0 & 0 & 1 & 0 & 0 & 0 & 0 & 0 \\
\hline Syria & 0 & 0 & 0 & 7 & 0 & 0 & 2 & 0 & 0 & 0 & 0 & 0 & 0 & 0 & 0 \\
\hline Taiwan & 18 & 81 & 64 & 31 & 8 & 3 & 3 & 2 & 1 & 3 & 1 & 3 & 3 & 2 & 0 \\
\hline Tajikistan & 0 & 0 & 0 & 0 & 0 & 0 & 0 & 0 & 0 & 0 & 1 & 0 & 0 & 0 & 0 \\
\hline Tanzania & 0 & 2 & 2 & 4 & 5 & 2 & 0 & 1 & 0 & 0 & 0 & 0 & 0 & 0 & 0 \\
\hline Thailand & 0 & 7 & 18 & 7 & 2 & 0 & 0 & 0 & 2 & 0 & 0 & 1 & 3 & 0 & 0 \\
\hline Timor Leste & 0 & 0 & 0 & 1 & 0 & 0 & 0 & 0 & 0 & 0 & 0 & 0 & 0 & 0 & 0 \\
\hline Tunisia & 0 & 0 & 1 & 4 & 6 & 6 & 0 & 3 & 0 & 0 & 0 & 0 & 1 & 0 & 0 \\
\hline Turkey & 19 & 27 & 83 & 39 & 12 & 9 & 5 & 16 & 14 & 7 & 12 & 24 & 19 & 2 & 0 \\
\hline Tuvalu & 0 & 0 & 0 & 0 & 0 & 1 & 0 & 0 & 0 & 0 & 0 & 0 & 0 & 0 & 0 \\
\hline Uganda & 0 & 0 & 8 & 7 & 0 & 2 & 0 & 0 & 0 & 0 & 0 & 0 & 0 & 0 & 0 \\
\hline Ukraine & 1 & 4 & 41 & 39 & 33 & 30 & 20 & 28 & 27 & 29 & 20 & 23 & 5 & 0 & 0 \\
\hline United Arab Emirates & 0 & 0 & 1 & 3 & 1 & 0 & 0 & 0 & 0 & 0 & 0 & 0 & 0 & 0 & 0 \\
\hline United Kingdom & 3 & 2 & 14 & 25 & 8 & 2 & 2 & 3 & 1 & 1 & 0 & 6 & 2 & 1 & 0 \\
\hline United States & 33 & 79 & 278 & 271 & 130 & 44 & 37 & 26 & 19 & 22 & 14 & 39 & 17 & 24 & 0 \\
\hline Uruguay & 0 & 0 & 3 & 0 & 0 & 0 & 0 & 0 & 0 & 0 & 0 & 0 & 0 & 0 & 0 \\
\hline Uzbekistan & 0 & 0 & 1 & 0 & 0 & 0 & 0 & 0 & 0 & 0 & 0 & 0 & 0 & 0 & 0 \\
\hline Vanuatu & 0 & 0 & 0 & 0 & 0 & 0 & 0 & 0 & 0 & 0 & 1 & 0 & 0 & 0 & 0 \\
\hline Venezuela & 1 & 8 & 18 & 11 & 7 & 5 & 5 & 3 & 0 & 0 & 1 & 2 & 3 & 0 & 0 \\
\hline Vietnam & 0 & 0 & 0 & 1 & 0 & 0 & 0 & 0 & 0 & 0 & 0 & 0 & 0 & 0 & 0 \\
\hline Western Sahara & 0 & 0 & 3 & 13 & 3 & 0 & 0 & 0 & 0 & 0 & 0 & 0 & 0 & 0 & 0 \\
\hline Yemen & 0 & 0 & 0 & 1 & 1 & 0 & 0 & 0 & 0 & 0 & 0 & 0 & 0 & 0 & 0 \\
\hline Zimbabwe & 0 & 0 & 2 & 0 & 0 & 0 & 0 & 1 & 0 & 0 & 0 & 0 & 0 & 0 & 0 \\
\hline
\end{tabular}




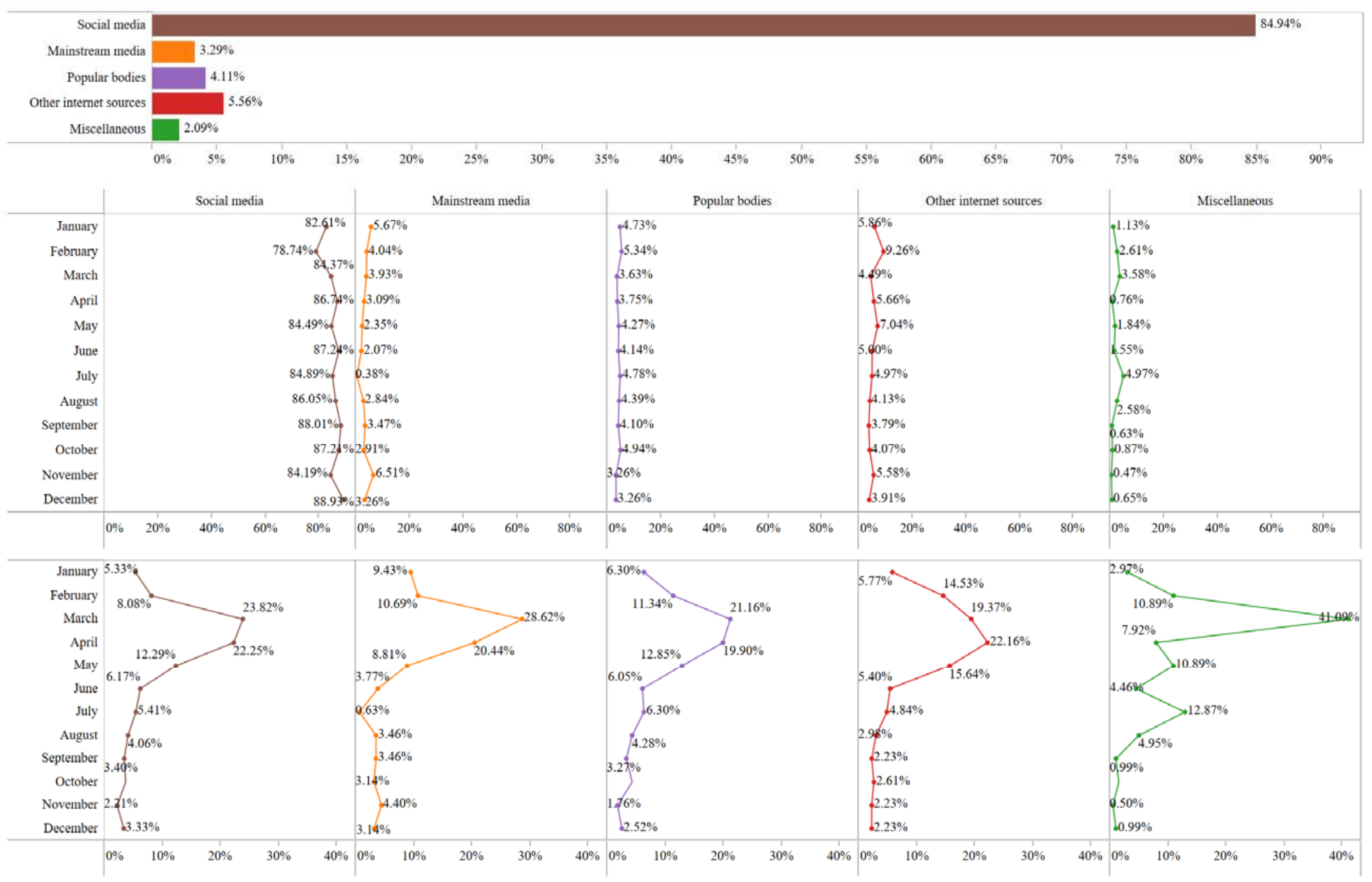

Figure 3. Details of the COVID-19 misinformation sources. 
medRxiv preprint doi: https://doi.org/10.1101/2021.05.08.21256879; this version posted May 12, 2021. The copyright holder for this preprint (which was not certified by peer review) is the author/funder, who has granted medRxiv a license to display the preprint in perpetuity.

It is made available under a CC-BY-NC-ND 4.0 International license .

Table 3. Various social media, mainstream media, and internet sources of misinformation.

\begin{tabular}{lll}
\hline Source & Frequency & Percentage \\
\hline Social media & 5485 & $66.87 \%$ \\
Facebook & 838 & $10.22 \%$ \\
WhatsApp & 831 & $10.13 \%$ \\
Social media (unspecified) & 674 & $8.22 \%$ \\
Twitter & 184 & $2.24 \%$ \\
YouTube & 82 & $1.00 \%$ \\
Line & 80 & $0.98 \%$ \\
Instagram & 15 & $0.18 \%$ \\
Telegram & 11 & $0.13 \%$ \\
TikTok & 3 & $0.04 \%$ \\
Weibo & 8203 & $100.00 \%$ \\
Total & & \\
Mainstream media & & \\
Mainstream media (unspecified) & 157 & $49.37 \%$ \\
Newspaper & 88 & $27.67 \%$ \\
Television & 66 & $20.75 \%$ \\
Radio & 7 & $2.20 \%$ \\
Total & 318 & $100.00 \%$ \\
Other internet sources & & \\
Online portal & & \\
Blog & 453 & $100 \%$ \\
Total & 84 & \\
\hline
\end{tabular}


Table 4. Sources of misinformation according to the countries.

\begin{tabular}{|c|c|c|c|c|c|}
\hline \multirow[t]{2}{*}{ Country } & \multicolumn{5}{|c|}{ Source of misinformation (\%) } \\
\hline & $\begin{array}{l}\text { Social } \\
\text { media }\end{array}$ & $\begin{array}{l}\text { Mainstream } \\
\text { media }\end{array}$ & $\begin{array}{l}\text { Popular } \\
\text { bodies }\end{array}$ & $\begin{array}{l}\text { Other internet } \\
\text { sources }\end{array}$ & Misc. \\
\hline Afghanistan & $0.02 \%$ & $0.00 \%$ & $0.00 \%$ & $0.00 \%$ & $0.00 \%$ \\
\hline Africa & $0.17 \%$ & $0.00 \%$ & $0.00 \%$ & $0.00 \%$ & $0.00 \%$ \\
\hline Albania & $0.01 \%$ & $0.00 \%$ & $0.00 \%$ & $0.00 \%$ & $0.00 \%$ \\
\hline Algeria & $0.09 \%$ & $0.00 \%$ & $0.00 \%$ & $0.16 \%$ & $0.47 \%$ \\
\hline Argentina & $2.30 \%$ & $2.24 \%$ & $2.56 \%$ & $0.81 \%$ & $1.89 \%$ \\
\hline Asia & $0.01 \%$ & $0.00 \%$ & $0.23 \%$ & $0.00 \%$ & $0.00 \%$ \\
\hline Australia & $1.42 \%$ & $0.00 \%$ & $0.23 \%$ & $0.32 \%$ & $0.00 \%$ \\
\hline Austria & $0.04 \%$ & $0.00 \%$ & $0.00 \%$ & $0.16 \%$ & $0.00 \%$ \\
\hline Azerbaijan & $0.01 \%$ & $0.00 \%$ & $0.00 \%$ & $0.16 \%$ & $0.00 \%$ \\
\hline Bahrain & $0.01 \%$ & $0.00 \%$ & $0.00 \%$ & $0.00 \%$ & $0.00 \%$ \\
\hline Belarus & $0.07 \%$ & $0.00 \%$ & $0.00 \%$ & $0.16 \%$ & $0.00 \%$ \\
\hline Belgium & $0.31 \%$ & $0.28 \%$ & $0.47 \%$ & $0.49 \%$ & $0.47 \%$ \\
\hline Bolivia & $0.47 \%$ & $0.56 \%$ & $1.63 \%$ & $0.16 \%$ & $8.96 \%$ \\
\hline Bosnia and Herzegovina & $0.09 \%$ & $3.08 \%$ & $0.23 \%$ & $2.59 \%$ & $0.47 \%$ \\
\hline Brazil & $9.17 \%$ & $1.40 \%$ & $9.77 \%$ & $5.83 \%$ & $0.94 \%$ \\
\hline Bulgaria & $0.01 \%$ & $0.28 \%$ & $0.23 \%$ & $0.00 \%$ & $0.00 \%$ \\
\hline Burkina Faso & $0.01 \%$ & $0.00 \%$ & $0.00 \%$ & $0.00 \%$ & $0.00 \%$ \\
\hline Burundi & $0.10 \%$ & $0.00 \%$ & $0.00 \%$ & $0.00 \%$ & $0.00 \%$ \\
\hline Cameroon & $0.07 \%$ & $0.00 \%$ & $0.00 \%$ & $0.16 \%$ & $0.00 \%$ \\
\hline Canada & $0.79 \%$ & $0.84 \%$ & $1.40 \%$ & $0.97 \%$ & $2.83 \%$ \\
\hline Central America & $0.01 \%$ & $0.00 \%$ & $0.00 \%$ & $0.00 \%$ & $0.00 \%$ \\
\hline Chile & $0.09 \%$ & $0.00 \%$ & $0.00 \%$ & $0.00 \%$ & $0.00 \%$ \\
\hline China & $0.36 \%$ & $0.00 \%$ & $0.00 \%$ & $0.16 \%$ & $0.00 \%$ \\
\hline Colombia & $3.83 \%$ & $2.80 \%$ & $3.02 \%$ & $4.85 \%$ & $1.42 \%$ \\
\hline Congo & $0.12 \%$ & $0.00 \%$ & $0.00 \%$ & $0.00 \%$ & $0.00 \%$ \\
\hline Costa Rica & $0.42 \%$ & $0.00 \%$ & $0.23 \%$ & $0.00 \%$ & $0.00 \%$ \\
\hline Croatia & $0.55 \%$ & $4.76 \%$ & $0.00 \%$ & $1.78 \%$ & $0.47 \%$ \\
\hline Cuba & $0.03 \%$ & $0.28 \%$ & $0.00 \%$ & $0.16 \%$ & $0.00 \%$ \\
\hline Czech Republic & $0.02 \%$ & $0.00 \%$ & $0.00 \%$ & $0.00 \%$ & $0.00 \%$ \\
\hline Denmark & $0.16 \%$ & $0.00 \%$ & $0.00 \%$ & $0.16 \%$ & $0.47 \%$ \\
\hline Dominican Republic & $0.01 \%$ & $0.00 \%$ & $0.00 \%$ & $0.00 \%$ & $0.00 \%$ \\
\hline East Africa & $0.13 \%$ & $0.84 \%$ & $0.23 \%$ & $0.00 \%$ & $0.00 \%$ \\
\hline Ecuador & $1.05 \%$ & $0.00 \%$ & $0.00 \%$ & $0.16 \%$ & $0.00 \%$ \\
\hline Egypt & $0.47 \%$ & $0.00 \%$ & $0.00 \%$ & $0.00 \%$ & $0.00 \%$ \\
\hline El Salvador & $0.01 \%$ & $0.00 \%$ & $0.23 \%$ & $0.00 \%$ & $0.47 \%$ \\
\hline Ethiopia & $0.07 \%$ & $0.00 \%$ & $0.00 \%$ & $0.32 \%$ & $0.00 \%$ \\
\hline Europe & $0.06 \%$ & $0.28 \%$ & $0.00 \%$ & $0.16 \%$ & $0.00 \%$ \\
\hline Fiji & $0.01 \%$ & $0.00 \%$ & $0.00 \%$ & $0.00 \%$ & $0.00 \%$ \\
\hline Finland & $0.02 \%$ & $0.00 \%$ & $0.00 \%$ & $0.00 \%$ & $0.00 \%$ \\
\hline France & $3.18 \%$ & $1.96 \%$ & $6.28 \%$ & $4.69 \%$ & $3.30 \%$ \\
\hline Gabon & $0.02 \%$ & $0.00 \%$ & $0.00 \%$ & $0.16 \%$ & $0.00 \%$ \\
\hline Gambia & $0.01 \%$ & $0.00 \%$ & $0.00 \%$ & $0.00 \%$ & $0.00 \%$ \\
\hline Georgia & $1.87 \%$ & $8.40 \%$ & $0.47 \%$ & $1.94 \%$ & $0.00 \%$ \\
\hline Germany & $1.16 \%$ & $0.28 \%$ & $0.47 \%$ & $3.56 \%$ & $0.00 \%$ \\
\hline Ghana & $0.39 \%$ & $0.00 \%$ & $0.00 \%$ & $1.62 \%$ & $0.00 \%$ \\
\hline Greece & $0.17 \%$ & $7.84 \%$ & $0.23 \%$ & $2.91 \%$ & $0.94 \%$ \\
\hline Guatemala & $0.12 \%$ & $0.00 \%$ & $0.47 \%$ & $0.16 \%$ & $0.00 \%$ \\
\hline Guinea & $0.02 \%$ & $0.00 \%$ & $0.00 \%$ & $0.00 \%$ & $0.00 \%$ \\
\hline Honduras & $0.01 \%$ & $0.00 \%$ & $0.00 \%$ & $0.00 \%$ & $0.00 \%$ \\
\hline Hong Kong & $0.37 \%$ & $0.00 \%$ & $0.23 \%$ & $0.00 \%$ & $0.47 \%$ \\
\hline Hungary & $0.01 \%$ & $0.00 \%$ & $0.00 \%$ & $0.00 \%$ & $0.00 \%$ \\
\hline Iceland & $0.02 \%$ & $0.00 \%$ & $0.00 \%$ & $0.00 \%$ & $0.00 \%$ \\
\hline India & $18.07 \%$ & $8.12 \%$ & $3.95 \%$ & $2.75 \%$ & $1.89 \%$ \\
\hline Indonesia & $1.07 \%$ & $0.28 \%$ & $1.40 \%$ & $1.94 \%$ & $0.00 \%$ \\
\hline
\end{tabular}




\begin{tabular}{|c|c|c|c|c|c|}
\hline Iran & $0.08 \%$ & $0.28 \%$ & $0.47 \%$ & $0.00 \%$ & $0.47 \%$ \\
\hline Iraq & $0.08 \%$ & $0.00 \%$ & $0.00 \%$ & $0.00 \%$ & $0.00 \%$ \\
\hline Ireland & $0.90 \%$ & $0.28 \%$ & $0.00 \%$ & $0.16 \%$ & $0.00 \%$ \\
\hline Israel & $0.13 \%$ & $0.84 \%$ & $0.00 \%$ & $0.00 \%$ & $0.00 \%$ \\
\hline Italy & $2.11 \%$ & $3.36 \%$ & $1.40 \%$ & $3.72 \%$ & $0.00 \%$ \\
\hline Ivory Coast & $0.09 \%$ & $0.00 \%$ & $0.00 \%$ & $0.00 \%$ & $0.00 \%$ \\
\hline Japan & $0.50 \%$ & $0.28 \%$ & $0.47 \%$ & $1.13 \%$ & $1.42 \%$ \\
\hline Jordan & $0.19 \%$ & $0.00 \%$ & $0.00 \%$ & $0.00 \%$ & $0.00 \%$ \\
\hline Kazakhstan & $0.17 \%$ & $0.28 \%$ & $0.47 \%$ & $1.94 \%$ & $0.47 \%$ \\
\hline Kenya & $0.98 \%$ & $2.24 \%$ & $0.47 \%$ & $2.59 \%$ & $0.47 \%$ \\
\hline Kosovo & $0.01 \%$ & $0.00 \%$ & $0.00 \%$ & $0.00 \%$ & $0.00 \%$ \\
\hline Kuwait & $0.01 \%$ & $0.00 \%$ & $0.00 \%$ & $0.16 \%$ & $0.00 \%$ \\
\hline Kyrgyzstan & $0.04 \%$ & $0.28 \%$ & $0.23 \%$ & $0.65 \%$ & $0.00 \%$ \\
\hline Latvia & $0.18 \%$ & $0.00 \%$ & $1.40 \%$ & $0.16 \%$ & $0.00 \%$ \\
\hline Lebanon & $0.04 \%$ & $0.00 \%$ & $0.00 \%$ & $0.00 \%$ & $0.00 \%$ \\
\hline Libya & $0.03 \%$ & $0.00 \%$ & $0.00 \%$ & $0.00 \%$ & $0.00 \%$ \\
\hline Lithuania & $0.50 \%$ & $0.56 \%$ & $0.70 \%$ & $0.16 \%$ & $2.36 \%$ \\
\hline Madagascar & $0.09 \%$ & $0.00 \%$ & $0.23 \%$ & $0.00 \%$ & $0.00 \%$ \\
\hline Malawi & $0.01 \%$ & $0.00 \%$ & $0.00 \%$ & $0.00 \%$ & $0.00 \%$ \\
\hline Malaysia & $0.14 \%$ & $0.00 \%$ & $0.00 \%$ & $0.00 \%$ & $0.00 \%$ \\
\hline Mali & $0.11 \%$ & $0.00 \%$ & $0.00 \%$ & $0.00 \%$ & $0.00 \%$ \\
\hline Mexico & $2.66 \%$ & $1.12 \%$ & $0.23 \%$ & $0.65 \%$ & $0.94 \%$ \\
\hline Middle East & $1.29 \%$ & $0.00 \%$ & $0.00 \%$ & $0.00 \%$ & $0.00 \%$ \\
\hline Missing & $0.77 \%$ & $1.12 \%$ & $1.16 \%$ & $0.00 \%$ & $28.77 \%$ \\
\hline Moldova & $0.01 \%$ & $0.00 \%$ & $0.00 \%$ & $0.00 \%$ & $0.00 \%$ \\
\hline Montenegro & $0.01 \%$ & $0.56 \%$ & $0.00 \%$ & $0.00 \%$ & $0.00 \%$ \\
\hline Morocco & $0.10 \%$ & $0.00 \%$ & $0.00 \%$ & $0.32 \%$ & $0.00 \%$ \\
\hline Myanmar & $0.71 \%$ & $0.00 \%$ & $0.00 \%$ & $0.16 \%$ & $0.00 \%$ \\
\hline Netherlands & $0.18 \%$ & $0.56 \%$ & $0.70 \%$ & $0.81 \%$ & $0.47 \%$ \\
\hline New Zealand & $0.18 \%$ & $0.00 \%$ & $0.00 \%$ & $0.00 \%$ & $0.00 \%$ \\
\hline Nigeria & $1.00 \%$ & $0.56 \%$ & $0.23 \%$ & $1.78 \%$ & $0.94 \%$ \\
\hline North Africa & $1.12 \%$ & $0.00 \%$ & $0.00 \%$ & $0.00 \%$ & $0.00 \%$ \\
\hline North America & $0.02 \%$ & $0.00 \%$ & $0.00 \%$ & $0.00 \%$ & $0.00 \%$ \\
\hline North Korea & $0.00 \%$ & $0.00 \%$ & $0.00 \%$ & $0.16 \%$ & $0.00 \%$ \\
\hline North Macedonia & $1.20 \%$ & $2.52 \%$ & $0.70 \%$ & $7.12 \%$ & $1.42 \%$ \\
\hline Norway & $0.02 \%$ & $0.00 \%$ & $0.00 \%$ & $0.00 \%$ & $0.00 \%$ \\
\hline Oman & $0.01 \%$ & $0.00 \%$ & $0.00 \%$ & $0.00 \%$ & $0.00 \%$ \\
\hline Pakistan & $0.22 \%$ & $0.00 \%$ & $0.00 \%$ & $0.00 \%$ & $0.94 \%$ \\
\hline Papua-New-Guinea & $0.01 \%$ & $0.00 \%$ & $0.00 \%$ & $0.00 \%$ & $0.00 \%$ \\
\hline Paraguay & $0.17 \%$ & $0.56 \%$ & $0.93 \%$ & $0.00 \%$ & $0.00 \%$ \\
\hline Peru & $0.29 \%$ & $0.00 \%$ & $1.16 \%$ & $0.00 \%$ & $0.00 \%$ \\
\hline Philippines & $2.98 \%$ & $0.56 \%$ & $8.60 \%$ & $4.69 \%$ & $1.42 \%$ \\
\hline Poland & $0.69 \%$ & $0.56 \%$ & $0.23 \%$ & $3.07 \%$ & $0.00 \%$ \\
\hline Portugal & $0.87 \%$ & $0.00 \%$ & $0.23 \%$ & $0.97 \%$ & $1.89 \%$ \\
\hline Qatar & $0.01 \%$ & $0.00 \%$ & $0.00 \%$ & $0.00 \%$ & $0.00 \%$ \\
\hline Romania & $0.02 \%$ & $0.00 \%$ & $0.23 \%$ & $0.00 \%$ & $0.00 \%$ \\
\hline Russia & $0.31 \%$ & $0.28 \%$ & $0.47 \%$ & $1.94 \%$ & $0.00 \%$ \\
\hline Rwanda & $0.01 \%$ & $0.00 \%$ & $0.00 \%$ & $0.00 \%$ & $0.00 \%$ \\
\hline Saudi Arabia & $0.10 \%$ & $0.00 \%$ & $0.00 \%$ & $0.00 \%$ & $0.00 \%$ \\
\hline Senegal & $0.08 \%$ & $0.00 \%$ & $0.00 \%$ & $0.00 \%$ & $0.00 \%$ \\
\hline Serbia & $0.11 \%$ & $2.24 \%$ & $1.63 \%$ & $1.62 \%$ & $0.00 \%$ \\
\hline Singapore & $0.11 \%$ & $0.00 \%$ & $0.00 \%$ & $0.00 \%$ & $0.00 \%$ \\
\hline Slovakia & $0.01 \%$ & $0.00 \%$ & $0.00 \%$ & $0.00 \%$ & $0.00 \%$ \\
\hline South Africa & $0.46 \%$ & $0.00 \%$ & $0.23 \%$ & $0.16 \%$ & $0.00 \%$ \\
\hline South America & $0.02 \%$ & $0.00 \%$ & $0.00 \%$ & $0.00 \%$ & $0.00 \%$ \\
\hline South Korea & $0.24 \%$ & $0.56 \%$ & $0.23 \%$ & $0.00 \%$ & $0.00 \%$ \\
\hline South Sudan & $0.03 \%$ & $0.00 \%$ & $0.00 \%$ & $0.00 \%$ & $0.47 \%$ \\
\hline Southern Africa & $0.04 \%$ & $0.00 \%$ & $0.00 \%$ & $0.00 \%$ & $0.00 \%$ \\
\hline Spain & $7.83 \%$ & $6.72 \%$ & $6.98 \%$ & $6.63 \%$ & $25.00 \%$ \\
\hline Sri Lanka & $1.29 \%$ & $0.00 \%$ & $0.00 \%$ & $0.49 \%$ & $0.00 \%$ \\
\hline
\end{tabular}


medRxiv preprint doi: https://doi.org/10.1101/2021.05.08.21256879; this version posted May 12, 2021. The copyright holder for this preprint (which was not certified by peer review) is the author/funder, who has granted medRxiv a license to display the preprint in perpetuity.

It is made available under a CC-BY-NC-ND 4.0 International license .

\begin{tabular}{|c|c|c|c|c|c|}
\hline Sudan & $0.01 \%$ & $0.00 \%$ & $0.00 \%$ & $0.00 \%$ & $0.00 \%$ \\
\hline Sweden & $0.06 \%$ & $0.28 \%$ & $0.23 \%$ & $0.16 \%$ & $0.00 \%$ \\
\hline Switzerland & $0.02 \%$ & $0.00 \%$ & $0.00 \%$ & $0.00 \%$ & $0.00 \%$ \\
\hline Syria & $0.10 \%$ & $0.00 \%$ & $0.00 \%$ & $0.00 \%$ & $0.00 \%$ \\
\hline Taiwan & $2.38 \%$ & $0.56 \%$ & $0.00 \%$ & $0.49 \%$ & $1.89 \%$ \\
\hline Tajikistan & $0.01 \%$ & $0.00 \%$ & $0.00 \%$ & $0.00 \%$ & $0.00 \%$ \\
\hline Tanzania & $0.11 \%$ & $0.00 \%$ & $0.00 \%$ & $0.97 \%$ & $0.00 \%$ \\
\hline Thailand & $0.42 \%$ & $0.00 \%$ & $0.00 \%$ & $0.00 \%$ & $0.94 \%$ \\
\hline Timor Leste & $0.01 \%$ & $0.00 \%$ & $0.00 \%$ & $0.00 \%$ & $0.00 \%$ \\
\hline Tunisia & $0.22 \%$ & $0.00 \%$ & $0.00 \%$ & $0.16 \%$ & $0.00 \%$ \\
\hline Turkey & $2.48 \%$ & $12.32 \%$ & $0.70 \%$ & $2.91 \%$ & $0.00 \%$ \\
\hline Tuvalu & $0.01 \%$ & $0.00 \%$ & $0.00 \%$ & $0.00 \%$ & $0.00 \%$ \\
\hline Uganda & $0.14 \%$ & $0.00 \%$ & $0.23 \%$ & $0.49 \%$ & $0.00 \%$ \\
\hline Ukraine & $3.15 \%$ & $2.80 \%$ & $0.47 \%$ & $0.65 \%$ & $0.47 \%$ \\
\hline United Arab Emirates & $0.06 \%$ & $0.00 \%$ & $0.00 \%$ & $0.00 \%$ & $0.00 \%$ \\
\hline United Kingdom & $0.69 \%$ & $1.12 \%$ & $0.23 \%$ & $0.49 \%$ & $0.00 \%$ \\
\hline United States & $8.61 \%$ & $11.20 \%$ & $31.16 \%$ & $12.94 \%$ & $2.36 \%$ \\
\hline Uruguay & $0.03 \%$ & $0.00 \%$ & $0.00 \%$ & $0.00 \%$ & $0.00 \%$ \\
\hline Uzbekistan & $0.01 \%$ & $0.00 \%$ & $0.00 \%$ & $0.00 \%$ & $0.00 \%$ \\
\hline Vanuatu & $0.01 \%$ & $0.00 \%$ & $0.00 \%$ & $0.00 \%$ & $0.00 \%$ \\
\hline Venezuela & $0.50 \%$ & $0.56 \%$ & $3.26 \%$ & $0.00 \%$ & $1.42 \%$ \\
\hline Vietnam & $0.00 \%$ & $0.28 \%$ & $0.00 \%$ & $0.00 \%$ & $0.00 \%$ \\
\hline Western Sahara & $0.21 \%$ & $0.00 \%$ & $0.00 \%$ & $0.00 \%$ & $0.00 \%$ \\
\hline Yemen & $0.02 \%$ & $0.00 \%$ & $0.00 \%$ & $0.00 \%$ & $0.00 \%$ \\
\hline Zimbabwe & $0.03 \%$ & $0.00 \%$ & $0.00 \%$ & $0.00 \%$ & $0.00 \%$ \\
\hline
\end{tabular}

